\title{
The Impact of Automation and Knowledge Workers on Employees' Outcomes: Mediating Role of Knowledge Transfer
}

\author{
Ndingi Junior Itoe Mote * and Georgiana Karadas
}

Business Administration, Cyprus International University, Lefkosa 99010, Turkey; gkaradas@ciu.edu.tr

* Correspondence: ndingij@@gmail.com or 20168254@student.ciu.edu.tr

\begin{abstract}
While there are existing empirical reviews regarding the relation between knowledge workers (KW) and knowledge transfer (KT), no study has examined the association of automation and knowledge transfer. The study describes knowledge workers as employees embedded with special abilities and having the main role of transfering their abilities to other workers in the organization. Additionally, automation (AUT) is described in the study as a technological process embedded with tacit knowledge. Therefore, using knowledge worker productivity theory and the technology acceptance model, this study aims to recommend and test a research model which examines the mediating role of knowledge transfer between automation, knowledge workers, and employee outcomes (employee creativity (EC) and innovative performance (IP)). The study evaluates the significant influence of knowledge transfer on innovative performance and creativity of other employees within the organization. This study applied a judgmental non-probability sampling research strategy to gather data from employees at an industrial firm in Japan by administering a questionnaire via Google Form. The data were analyzed with partial least squares based on structural equation modeling aimed at testing the predictive power and relationships of the model estimates. The results found support for the mediating role of knowledge transfer between automation and employee creativity as well as between automation and innovative performance. However, the study found partial support that knowledge transfer mediates the relationship between knowledge worker and employee creativity, as well as knowledge worker and innovative performance. In the same, automation and knowledge workers have significant impacts on knowledge transfer. Knowledge transfer has a significant impact on employee creativity and innovative performance.
\end{abstract}

Keywords: knowledge transfer; automation; knowledge worker; employee creativity; innovative performance

\section{Introduction}

The rise of competition between organizations has pushed the management of organizations to embark on sustainable measures to remain competitive [1]. This has caused many organizations to resort to resources embedded with knowledge for successful competition, such as automation and knowledge workers. Many scholars have carried out research differentiating the knowledge worker from other workers [2,3]. What differentiates knowledge workers from other workers is the set of skills they possess and the competence they exhibit, which tend to have a noteworthy impact on other workers and the organization as a whole $[2,3]$. Core knowledge is the main quality that enables knowledge workers to compete from an expert position, thereby setting them apart from other workers [3]. Other workers, over time, reach the level of knowledge workers as they gain core knowledge and become more innovative and creative [3]. The term knowledge worker will be used all through this research to refer to workers embedded with knowledge and special abilities and who facilitate the process of knowledge transfer to other workers in the organization.

The resource-based theory demands organizations effectively use their resources and skills to enhance productivity [4]. As a result, many organizations have shifted 
their paradigm from physical labor to "knowledge capital" such as knowledge workers, automation, and artificial intelligence, while many jobs that are formally done by humans are now being performed by machines [5]. Several scholars have predicted that knowledge workers and automation would take over more than 140 million full-time jobs within the organization by $2025[5,6]$. The increased application of automation within organizations has reduced the role of traditional labor workers [5]. That notwithstanding, not every job will be replaced by machines as the role of knowledge workers in the organization remains unmatched by machines [7]. The contributions of humans will have a more qualitative nature, such as innovative and creative proficiencies, which are the qualities of knowledge workers $[5,8,9]$ while automation will boost the productivity process and ease the workflow, thereby allowing the knowledge workers and other workers to move away from mundane routines into high-value activities within the organization [10].

Knowledge management is described as the process of converting tacit knowledge into explicit knowledge, allowing knowledge to move freely throughout an organization [11]. Explicit knowledge is any knowledge that can be articulated, codified, verbalized, and communicated. Explicit knowledge can be systematized and stored in a knowledge database, or it can be incorporated into technological or organizational routines. In management and organizational learning, explicit knowledge plays a significant role in decision-making [12]. People may connect, learn from one another, and so develop new knowledge [13]. Therefore, knowledge workers are knowledge bases embedded in explicit knowledge. Unlike explicit knowledge, tacit knowledge resides in people's thoughts and is unwritten and concealed [14]. Because tacit knowledge is obtained through experience and interactions with others, it is more difficult to transmit to others than explicit knowledge [15]. As a result, the machine is a knowledge database with tacit knowledge incorporated in it.

However, this knowledge embedded in knowledge workers and automation cannot be used to improve the organization if it cannot be applied (i.e., transferred from the sources to where needed). As a result, many organizations are building their systems to promote employee creativity and innovative performance through the transfer of knowledge within the organization [16]. Knowledge transfer moderates organizations' practices, thereby inspiring innovative performance and employee creativity [17]. The theory of knowledge worker productivity posits knowledge workers as significant assets within the organization who play a significant role in transferring knowledge within the organization $[18,19]$. Apart from the study of Rodriguez et al. [20] which examined the relationship between robot systems and knowledge transfer, focusing on knowledge transfer as an outcome and automation as an antecedent, several other studies examined knowledge transfer as an antecedent and automation as an outcome [21]. The theory of technology acceptance model (TAM) also posits that automation is essential for knowledge transfer [22].

Therefore, using data from an industrial firm in Japan, the purpose of this study is to:

(1) Examine the significance of knowledge workers and automation on knowledge transfer.

(2) Examine how automation and knowledge workers can enhance the creativity and innovative performance of other employees.

(3) Examine the role of knowledge transfer in mediating the relationship between (a) automation and employee creativity; (b) automation and innovative performance; (c) knowledge worker and employee creativity; and (d) knowledge worker and innovative performance.

Knowledge creation, acquisition, transfer, and application are the four activities that most research on knowledge management looked at [15]. However, the current study focuses on knowledge transfer as a mechanism of facilitating the flow of information from the knowledge database to other parts of the company. This research looks at the contributions of knowledge workers and automation $[9,23]$ and evaluates their contributions to the organization in enhancing the creativity and innovative performances of all employees. 


\section{Contribution to the Literature}

While several past studies suggested that the activities of automation would replace human labor [5], other studies revealed that the knowledge worker and machine will complement each other [24-26]. Very little of the existing literature could highlight how knowledge workers' activities and automation have changed the entire structure of the organization. Therefore, this research demonstrates the significant role of the activities of knowledge workers and automation in creating and transferring knowledge within organizations. Secondly, by focusing on knowledge transfer as the underlining mechanism, this study displays how knowledge embedded in knowledge workers and automation can be generated for use, which can effectively enhance employee creativity and innovative performance. Finally, past studies have found that it is difficult to transfer knowledge [25]. This paper proves that automation and knowledge workers are knowledge resources which, through learning, enable other employees to acquire knowledge. Knowledge workers are capable of retaining, creating, transferring, and storing knowledge, which can be used to enhance other employees in the organization. The knowledge worker transfers knowledge through formal and informal interaction [25], while automation uses information technology services such as electronic databases, multimedia systems, and groupware to create knowledge $[27,28]$. Thus, this research provides guidelines to the management of organizations to manage automation and knowledge workers as worthy organizational resources for maximum sustainability.

The remainder of this paper is organized in the following manner: Section 2 will discuss the empirical review, the theoretical framework, and the stated hypotheses. Section 3 will explain the sampling technique, the sample size, data collection technique, and item measurement. The paper will then analyze the result and conclude with a discussion, research implications, and recommendations for future studies.

\section{Theory and Hypotheses Development}

\subsection{Knowledge Worker Productivity Theory}

Knowledge worker productivity theory is an improvement of the scientific management theory of Taylor which highlights the evolution of management from a labor-intensive perspective to a mechanized system composed of data and knowledge acquisition, information, intelligence systems, etc. [29]. The theory holds that knowledge forms the basis of high-tech organizations and other large organizations. The theory expresses the application of high technology as an expression of a knowledge society, specifically through the use of information and communication technology. New technologies such as the Internet of Things are aligning innovation to develop internal capacity for knowledge management [30], which helps organizations transfer knowledge from one sector to another and also helps monitor significant procedures that support the decision-making process [31]. Nevertheless, this advanced technology requires a new approach to management, often requiring the ongoing intervention of special skills possessed by knowledge workers to steer the workflow system [32].

Knowledge dynamics is a multifaceted process that affects individuals, groups, and organizations [11] and determines the scope and extent of knowledge management within an organization. Organizational knowledge may be incorporated into an organization's numerous structures, procedures, and rules through a diverse medium [33]. Nonaka and Takeuchi [34] demonstrated how socializing can be used to transfer an individual's tacit knowledge within a team and how explicit knowledge can be strengthened by integrating it in a social setting. As a result, knowledge is generated at the organizational level through cooperation, resulting in organizational knowledge and intellectual capital [34]. The capacity of an organization to utilize and harness knowledge is greatly reliant on members of the organization and knowledge workers [35]. Zaim et al. [36] found that organizations with better knowledge management practices tend to have higher human resource management performance, and vice versa. Learning is one such mechanism which eases knowledge transfer within [37] as it facilitates knowledge to move from knowledge bases 
such as knowledge workers to needed departments within the organization. Knowledge workers are the primary instruments of change within the organization [38] with the main responsibility to create, share, and apply knowledge [9]. In the 21st century, engaging knowledge workers in knowledge management is a major problem for organizations [39]. Employees transitioning from technically skilled workers to knowledge-based workers are at the heart of the knowledge worker revolution. Their intellectual capital has made knowledge workers a valuable asset for any organization [40]. The knowledge worker makes knowledge available for use within the organization [41]. From the above discussion, this study deduces that:

Hypothesis 1 (H1). The knowledge worker has a significant impact on knowledge transfer.

\subsection{Technology Acceptance Model}

The technology acceptance model (TAM) was developed by Davis [42] from the Theory of Reasoned Action [43]. The Theory of Reasoned Action holds as an assumption that employees' attitudes are influenced by their beliefs [43]. The main goal of the technology acceptance model is to provide a general model that explains the determinants of accepting new technologies within a community as well as the role of new technologies in improving performance [44]. The introduction of new technologies has the potential to enhance employees' abilities [45]. The study revealed that automation can substitute humans but also provide a contribution to the process of human labor to enhance human skills, providing a new interconnectedness that eases the flow of knowledge. The humanmachine interface has a high potential for improving employees' knowledge by syncing with the Internet of things devices to give new insight to information and data which boosts human efficiency [24]. The human-machine interface provides an atmosphere easy for the transfer of knowledge [25]. New technology such as the human-machine interface helps in extracting knowledge owned by workers and also enhances workers' efficiency by freeing time from repetitive tasks for more complex work [45]. Aly [46] examined the relationship between digital transformation and labor productivity and employment in developing countries. The research found a positive relationship between digital transformation and labor productivity. The research, however, revealed an insignificant relationship between digital transformation and vulnerable employment. Shimmura et al. [47] evaluated the contribution of robots in the restaurant industry and how it affects human productivity. The study revealed that the incorporation of robots improved human productivity by cutting off working time and increasing the quality of services. Luo et al. [48] examined the productivity of machines and humans by exploiting 6200 customers who received outbound sales calls. The study revealed that chatbots are as effective as expert workers and four times more efficient than inexperienced workers. Additionally, Cowgill [49] examined the role of machine learning technology in job interviews and acceptance in a field experiment for white-collar jobs. The study found that machine learning technology grants higher chances of passing an interview and receiving a job offer. From the above discussion on the technology acceptance model, this study hypothesizes the following:

Hypothesis 2 (H2). Automation has a significant impact on knowledge transfer.

\subsection{Empirical Review}

\subsubsection{Knowledge Worker and Employee Creativity}

Creativity is vital for an organization to support development and keep in touch with the latest trends in the industry [50]. Employee creativity has been examined with other elements such as organizational learning [51] and perceived organizational support [52]. Organizations can play a fundamental role in promoting employee creativity [53]. However, it takes the principal role of individual perception to determine the level of creativity of employees. Perceptions influence employees' background as well as cognitive abilities and limitations, which further influence employees' creative capability [54]. Practices such as 
special training and performance play key roles in improving employees' knowledge base, which is vital for employees' creativity [54]. Jeong and Shin [55] argued that enhanced training leads to the generation of better and greater solutions, as well as a great formation process. Additionally, researchers have also examined how organizations' rigorous policies such as learning positively impact employee creativity [56]. One important aspect of creativity is to see things differently from the perspective of others [57]. A learning organization is defined as one that fosters the learning process and offers opportunities for all of its members to gain knowledge [58]. As a result, rather than participating in extracurricular learning techniques, employees acquire job skills and experience in an informal manner [59]. Organizations that follow this method can boost team creativity and efficiently perform all required objectives [60]. Learning organizations assist employees to build and strengthen their creative capabilities [59]. Organizations usually do this by including workers in decision-making and evaluating workflows. This was viewed as a key component in boosting output and competitiveness [61]. The organization can instill a process of creativity by challenging employees to look beyond what is known, which will eventually lead to innovative changes [53]. Elsayed and Abdel-ghani [51] found a positive and significant correlation between learning organizations and employee creativity as employees' creativity increases in learning organizations. Organization's leaders are willing to have employees who are self-motivated to be creative [62]. Employees will be motivated to share their knowledge when the organization provides support for knowledge transfer [63]. Employees may advance their present knowledge, skills, and capacities via learning. Employee creativity adds more ideas for innovation when brainstorming sessions are conducted properly [64]. Organizations may take advantage of these innovative possibilities which can have a favorable influence on employee creativity and performance. This is an example of an employer's tacit understanding of a worker's thoughts. The learning process takes place largely during training and development programs that help employees improve their abilities and boost their worth as strategic assets [64]. This is especially true if the on-the-job training is customized to the organization. Organization-specific training, by definition, provides employees with abilities that are not easily transferable to other businesses. From the above discussion, this study hypothesizes that:

Hypothesis 3 (H3). Knowledge transfer has a significant impact on employee creativity.

\subsubsection{Knowledge Worker and Innovative Performance}

Most of the past studies on innovative performance have focused on innovative capability and innovative strategy [17], research and development of collaborative innovative performance [16], the innovative performance of competitive firms [65], and determinants of innovative performance [66]. Innovative performance is a critical means for organizations to combat sustainability challenges of the 21st century such as an open market and a high degree of competition [67]. As a result, organizations stand the risk of losing competitiveness to rivals if they fail to promote employees' innovative behavior. Consequently, most organizations of today will hardly survive market competition if management does not promote cultures or norms supportive of employees' innovativeness [68].

Organizations with the right work practices characterized by fun tend to have a higher tendency to be innovative [69]. Abdi et al. [70] pointed out that an organization's work design elements such as employee engagement positively affect innovativeness. Other researchers have looked at dispositional factors that stimulate innovative behaviors of employees in an organization, such as organizational learning, and found that organizational learning capacity has a positive effect on innovative performance [71]. Employee well-being and motivation to increase performance are the goals of the learning organization's strategy [72]. As a consequence, it enhances the organization's competitiveness and performance and has a beneficial impact on attaining the organization's goals and increases its efficiency. Furthermore, it equips employees with the knowledge necessary to deal with any workplace crisis, hence increasing employees' awareness. Learning organizations 
have discovered that workers are ideal sites to develop, acquire, and communicate knowledge [73]. Continuous progress in the innovative performance of employees necessitates a commitment to learning. Companies simply confront new difficulties and plan their tactics appropriately, according to DeLone and McLean [74], when a dynamic learning culture is introduced inside a company. With the introduction and application of new technology, learning organizations may affect employees' performance. Organizations and individuals that do not learn just replicate old, customary behaviors and easily become obsolete. Knowledge resource dynamics, particularly through organizational learning and cooperation, have a favorable influence on employees' innovative performance [64]. On the other side, organizational learning methods are utilized to gain a competitive advantage and add value to knowledge resources. Additionally, Acosta-Prado et al. [75] examined the mediating effect of knowledge management on management capability and innovative performance in knowledge-driven health provider institutions. The findings revealed that both management capability and knowledge management have positive effects on innovative performance. From the above discussion, this research hypothesizes that:

Hypothesis 4 (H4). Knowledge transfer has a significant impact on innovative performance.

\subsection{Mediating Role of Knowledge Transfer}

Organizations employ highly qualified employees who will increase the knowledge base of the organization and improve employees' outcomes through the activities of knowledge transfer [76]. Organizations also acquire knowledge resources such as automation to improve on. It is argued that knowledge transfer can function as a powerful facilitator for accomplishing organizational goals. Knowledge transfer entails either actively consulting other members of a group to acquire knowledge from knowledge resources such as knowledge workers and automation, or ensuring that these knowledge-embedded resources are capable of passing on their expertise to other members of the group [77]. Advanced means are, however, required for knowledge to be transferred from one sector of the organization to the other or from knowledge-intensive resources to other members within the organization. The nature of knowledge transfer can be summarized under three faculties: knowledge-related, organizational, and inter-organizational, with each of the three taking a different underlining approach [78]. It is the responsibility of the management of organizations to discover sources of knowledge within the organization, initiate methods to transfer this knowledge from one individual/sector to the other, and finally make it accessible in the most efficient manner for those in need of it [77]. Additionally, management can make use of knowledge innovatively and creatively to give significance as a standard part of employees' work. Transferring unique capabilities and knowledge assets owned by the target firms is frequently of marginal value, with few of them functionally void of major "investments" by the procuring firms [79]. Knowledge results in the birth of diverse capabilities in an organization, which facilitate the accomplishment of goals [30]. This argument is harmonious with the suggestion of Liu et al. [80], who argued that organizations with well-advanced knowledge exploitation and transformation capabilities are more prone to realizing absorptive capacity as well as accomplishing a competitive advantage via product development and innovation. From the above discussion on the knowledge worker productivity theory, this study hypothesizes the following:

Hypothesis 5 (H5). Knowledge transfer plays a mediating role between: (a) knowledge worker and employee creativity and (b) knowledge worker and innovative performance.

Hypothesis 6 (H6). Knowledge transfer plays a mediating role between: (a) automation and employee creativity and (b) automation and innovative performance. 


\section{Methods}

Most studies in management have applied deductive reasoning in their research methodology. Deductive reasoning needs to contain a structure of analytical reasoning for the research to arrive at a consensus [81]. The process of deductive reasoning ensures that the hypotheses have to be clarified as soon as the objective is specified, and the validity of the theories or hypotheses inferred from such a process depends on the capacity of scholars to identify the different elements of the research process logically [82]. As a result, this paper chose quantitative research in an attempt to engender a profound and in-depth understanding of the cause and effect relationship, which Hyde [83] argued that most studies with a quantitative approach have to adopt. Ciesielska and Jemielniak [84] also argued that there is no sole model or pattern to which management research must adhere. Hence, this study also found it appropriate to settle on quantitative research by focusing on some theories as well in the buildup of the hypotheses. This study applied non-probability sampling research, which enables the researcher to pick out the sample of the study based on subjective judgment. One such technique of non-probability sampling is judgmental sampling, which entails the researcher selecting the sample for the study based on their professional and knowledge experience. Other studies have also supported judgmental sampling, a non-probability sampling technique that requires a specific group of people to be targeted $[85,86]$. As a result, the study adopted measures to define the sample of the study. The judgmental sampling non-probability sampling technique must focus on a particular set of people [85].

The industrial firm in Japan has a total workforce of 16,690 employees. It would make sense if this universe of study focused on workers being affected by the activities of automation and knowledge workers. These employees have to possess special knowledge as their main qualification to be classified as creative and innovative. This notion, however, was difficult to follow through on because, while the firm has more than sixteen thousand employees, the human resource management was asked to direct the data collection specifically to engineers and other factory workers. Therefore, the total population of the firm was considered the universe of the study. The questionnaires were sent through Google Form to the human resource manager in an email, and the various supervisors followed up with their subordinates to provide data. The email was sent in June 2020, and by July, the data collection was completed. The minimum sample size for research with a total population of 16,690 employees, an error margin of $5 \%$, a confidence interval of $95 \%$, and a response distribution of $50 \%$ is 376 . Therefore, the link was closed to accepting more responses after 384 employees provided complete data.

The data was analyzed with partial least squares based on structural equation modelling. The structural model analysis aims to test the predictive power and relationships of the model estimates [87]. The following criteria facilitate the assessment of the structural model: collinearity assessment, model path coefficients analysis, coefficient of determination $\left(\mathrm{R}^{2}\right)$ analysis, and effect size $\left(\mathrm{F}^{2}\right)$ analysis. The procedure for these analyses in partial least squares structural equation modeling (PLS-SEM) includes the use of bootstrapping techniques to determine the significance of relationships.

The study is composed of two independent variables (knowledge worker and automation), one mediating variable (knowledge transfer), and two outcomes (employee creativity and innovative performance). The measurement of these variables will be treated subsequently. To measure automation, this study adopts Körber's [88] measures of nineteen questions using a five-point Likert scale from "strongly disagree" to "strongly agree". To measure knowledge workers, this study adopts Schwartz's [89] measures of seven items with a five-point Likert scale from "strongly disagree" to "strongly agree". To measure knowledge transfer, this study adopts Zahra and Bogner's [90] measures of eight items using a seven-point Likert scale from "strongly disagree" to "strongly agree". To measure employee creativity, this study adopts the questionnaire Zhou and George's [91] measures of thirteen questions using a five-point Likert scale from "strongly disagree" to "strongly agree". To measure innovative performance, this study adopts Matear et al.'s [92] mea- 
sures, consisting of six questions using a five-point Likert scale from "strongly disagree" to "strongly agree".

\section{Results}

\subsection{Demographic Analysis}

Table 1 presents the demographic characteristics of respondents. This includes age, gender, marriage, experience, and education. The result shows that the majority of the respondents are between 26 and 35 years old (43.5\%). Additionally, $27.1 \%$ of the respondents are 36-45 years old and respondents between 18 and 25 years old represent $3.1 \%$. Male respondents were more than female respondents. The result indicates that $74.2 \%$ of the respondents are male, while $25.8 \%$ are female. Additionally, the majority have a university first degree $(55.2 \%)$ with experience of between 1 and 5 years.

Table 1. Demographic characteristics of respondents.

\begin{tabular}{|c|c|c|c|}
\hline Demographic Variable & Measure & $\mathbf{N}$ & $\mathbf{N} \%$ \\
\hline \multirow{6}{*}{ Age } & 18-25 years old & 12 & 3.1 \\
\hline & 26-35 years old & 167 & 43.5 \\
\hline & $36-45$ years old & 104 & 27.1 \\
\hline & 46-45 years old & 72 & 18.8 \\
\hline & 56 years and above & 29 & 7.6 \\
\hline & Total & 384 & 100 \\
\hline \multirow{3}{*}{ Gender } & Male & 285 & 74.2 \\
\hline & Female & 99 & 25.8 \\
\hline & Total & 384 & 100 \\
\hline \multirow{3}{*}{ Marriage } & Single or divorced & 229 & 59.6 \\
\hline & Married & 155 & 40.4 \\
\hline & Total & 384 & 100 \\
\hline \multirow{7}{*}{ Work Experience } & Under 1 year & 71 & 18.5 \\
\hline & $1-5$ years & 171 & 44.5 \\
\hline & $6-10$ years & 82 & 21.4 \\
\hline & $11-15$ years & 43 & 11.2 \\
\hline & 16-20 years & 10 & 2.6 \\
\hline & More than 20 years & 7 & 1.8 \\
\hline & Total & 384 & 100.0 \\
\hline \multirow{6}{*}{ Education } & Primary school & 1 & 0.3 \\
\hline & Vocational school (two-year program) & 55 & 14.3 \\
\hline & Secondary school and high school & 73 & 19.0 \\
\hline & University first degree & 212 & 55.2 \\
\hline & Master or Ph.D. degree & 43 & 11.2 \\
\hline & Total & 384 & 100.0 \\
\hline
\end{tabular}

\subsection{Statistical Analysis}

This study applied partial least squares based on structural equation modelling (PLSSEM) to estimate the proposed composite models. This is to test and estimate causal relationships among hypothetical relationships and latent variables simultaneously. Advanced analysis of composites version 2.0.1 software (Adanco Group, Yung Kang, Taiwan) was used to estimate the model fit as suggested by Henseler [93]. It has been tested in management and social science research $[94,95]$. Furthermore, the two-step process of PLS-SEM was used for the analysis of the measurement model and structural model. The measurement model uses certain measures to determine the reliability and validity of items to determine the level of correlation. This also validates the adequacy of the measure of model constructs [96]. The second process is the structural model, which determines the path analysis for the internal model. Before the two-step process, a preliminary assessment of model fit needs to be determined, which includes the Standardized Root Mean 
Squared Residual (SRMR), unweighted least squares discrepancy (d_ULS), and geodesic discrepancy $\left(d_{-G}\right)$ [97]. The model fit is valid when the SRMR is less than 0.08; the squared Euclidean distance (d_ULS) is less than bootstrapped $\mathrm{HI}_{95} \%$ of $\mathrm{d}_{-\mathrm{ULS}}$; and $\mathrm{d}_{-} \mathrm{G}$ is less than bootstrapped $\mathrm{HI}_{95} \%$ [93]. Therefore, the results from Table 2 show that SRMR is lesser than 0.08 , $\mathrm{d}_{-}$ULS sat is less than $\mathrm{HI}_{95} \%$, and $\mathrm{d}_{-\mathrm{G}}$ sat is less than $\mathrm{HI}_{95} \%$, which shows a satisfactory result according to Henseler's [93] recommendation.

Table 2. Saturated model fits.

\begin{tabular}{cccc}
\hline \multirow{2}{*}{ Discrepancy } & \multicolumn{3}{c}{ Overall Saturated Model Fit Evaluation } \\
\cline { 2 - 4 } & Value & HI $_{\mathbf{9 5}}$ & Conclusion \\
\hline SRMR $<0.08$ & 0.067 & 0.078 & Support \\
d_ULS $<\mathrm{HI}_{95}$ & 2.828 & 6.599 & Support \\
d_G $<\mathrm{HI}_{95}$ & 3.242 & 3.998 & Support \\
\hline
\end{tabular}

This paper also adopted the evaluation of measurement models following guidelines from Hair et al. [98] to assess the measurement model for indicator reliability, internal consistency (composite reliability), convergent validity (AVE), and discriminant validity. Table 3 presents the assessment of the reliability of the attitudinal constructs. The indicator and construct reliability were assessed using Cronbach's Alpha, composite reliability, and average variance (AVE) measures. The analysis used the recommended thresholds for indicator loadings greater than 0.6 [98,99], Cronbach Alpha greater than 0.6 [98], composite reliability (CR) greater than 0.7 [100], and AVE greater than 0.5 [98].

Table 3. Reliability measurements.

\begin{tabular}{|c|c|c|c|c|c|c|}
\hline Constructs & Items & Loadings & VIF & CR & Cronbach's Alpha & AVE \\
\hline \multirow{8}{*}{ KT } & KT1 & 0.678 & 1.412 & \multirow{8}{*}{0.933} & \multirow{8}{*}{0.925} & \multirow{8}{*}{0.53} \\
\hline & KT2 & 0.693 & 1.653 & & & \\
\hline & KT3 & 0.677 & 1.585 & & & \\
\hline & KT4 & 0.698 & 1.448 & & & \\
\hline & KT5 & 0.622 & 1.403 & & & \\
\hline & KT6 & 0.697 & 1.392 & & & \\
\hline & KT7 & 0.709 & 1.633 & & & \\
\hline & KT8 & 0.700 & 1.561 & & & \\
\hline \multirow{16}{*}{ AUT } & AUT1 & 0.665 & 2.049 & \multirow{16}{*}{0.931} & \multirow{16}{*}{0.910} & \multirow{16}{*}{0.50} \\
\hline & AUT2 & 0.729 & 2.636 & & & \\
\hline & AUT3 & 0.646 & 2.103 & & & \\
\hline & AUT4 & 0.759 & 3.202 & & & \\
\hline & AUT5 & 0.794 & 3.241 & & & \\
\hline & AUT6 & 0.803 & 3.442 & & & \\
\hline & AUT7 & 0.762 & 2.710 & & & \\
\hline & AUT8 & 0.756 & 3.232 & & & \\
\hline & AUT9 & 0.808 & 2.822 & & & \\
\hline & AUT10 & 0.568 & 1.797 & & & \\
\hline & AUT11 & 0.680 & 2.965 & & & \\
\hline & AUT12 & 0.690 & 2.281 & & & \\
\hline & AUT13 & 0.666 & 2.811 & & & \\
\hline & AUT14 & 0.785 & 3.356 & & & \\
\hline & AUT15 & 0.645 & 1.541 & & & \\
\hline & AUT17 & 0.860 & 4.193 & & & \\
\hline \multirow{3}{*}{ KW } & KW1 & 0.756 & 1.745 & \multirow{3}{*}{0.797} & \multirow{3}{*}{0.702} & \multirow{3}{*}{0.56} \\
\hline & KW2 & 0.668 & 1.176 & & & \\
\hline & KW3 & 0.570 & 1.205 & & & \\
\hline
\end{tabular}


Table 3. Cont.

\begin{tabular}{|c|c|c|c|c|c|c|}
\hline Constructs & Items & Loadings & VIF & CR & Cronbach's Alpha & AVE \\
\hline & KW4 & 0.693 & 1.623 & & & \\
\hline & KW5 & 0.570 & 1.200 & & & \\
\hline & KW6 & 0.601 & 1.235 & & & \\
\hline & KW7 & 0.519 & 1.125 & & & \\
\hline \multirow{13}{*}{ EC } & EC1 & 0.650 & 1.323 & \multirow{13}{*}{0.826} & \multirow{13}{*}{0.775} & \multirow{13}{*}{0.671} \\
\hline & EC2 & 0.684 & 1.137 & & & \\
\hline & EC3 & 0.620 & 1.509 & & & \\
\hline & EC4 & 0.667 & 1.205 & & & \\
\hline & EC5 & 0.632 & 1.139 & & & \\
\hline & EC6 & 0.629 & 1.284 & & & \\
\hline & EC7 & 0.704 & 1.272 & & & \\
\hline & EC8 & 0.667 & 1.298 & & & \\
\hline & EC9 & 0.772 & 1.436 & & & \\
\hline & EC10 & 0.601 & 1.290 & & & \\
\hline & EC11 & 0.633 & 1.237 & & & \\
\hline & EC12 & 0.601 & 1.226 & & & \\
\hline & EC13 & 0.646 & 1.535 & & & \\
\hline \multirow{6}{*}{ IP } & IP1 & 0.777 & 1.735 & \multirow{6}{*}{0.866} & \multirow{6}{*}{0.816} & \multirow{6}{*}{0.523} \\
\hline & IP2 & 0.715 & 1.504 & & & \\
\hline & IP3 & 0.646 & 1.263 & & & \\
\hline & IP4 & 0.687 & 1.447 & & & \\
\hline & IP5 & 0.762 & 1.646 & & & \\
\hline & IP6 & 0.819 & 1.884 & & & \\
\hline
\end{tabular}

Any VIF (variance inflation factor) less than 5 (VIF < 5) shows no collinearity [98], and the VIF results presented in Table 3 show that the VIF values were less than the threshold, which indicates no collinearity among the items. First, it is the preliminary check for the level of collinearity among items and Variance Inflation Factors (VIF), which are applied to check for any collinearity issues [101]. The items met the required offset-loadings of greater than 0.6 as suggested by Hair et al. [98]. The items also met the required AVE greater than 0.5 (AVE > 0.5) as indicated by Hair et al. [98], the composite reliability greater than 0.7 $(\mathrm{CR}>0.7)$ as suggested by Gefen et al. [100], and Cronbach alpha greater than $0.6(\mathrm{Cf}>0.6)$ as suggested by Hair et al. [98].

Furthermore, the measurement estimates include cross-loading values, Fornell and Larcker's [102] criterion, and Heterotrait-Monotrait (HTMT) ratio analysis to check the discriminant validity. Table 4 presents the estimates of discriminant validity for each construct as recommended by Fornell and Larcker [102], which states that the square root of the AVE of each construct should be greater than the correlation between the constructs and other latent constructs.

Table 4. Discriminant validity.

\begin{tabular}{cccccc}
\hline Construct & IP & EC & KW & AUT & KT \\
\hline IP & 0.523 & & & & \\
EC & 0.270 & 0.671 & & & \\
KW & 0.102 & 0.086 & 0.564 & & \\
AUT & 0.154 & 0.092 & 0.236 & 0.504 & \\
KT & 0.281 & 0.185 & 0.197 & 0.094 & 0.539 \\
\hline
\end{tabular}

\subsection{Hypotheses Testing}

Further, this study estimates relationships between the proposed model estimates. The purpose is to measure the model fit of any proposed model [103]. As shown in Table 4, the study's results indicate that knowledge workers show a significant impact on knowledge transfer $(\beta=0.703, p<0.001)$, automation shows a significant impact on knowledge transfer 
( $\beta=0.315, p<0.001)$; and knowledge transfer shows a significant impact on employee creativity $(\beta=0.613, p<0.001)$. Finally, knowledge transfer shows a significant impact on innovative performance $(\beta=0.703, p<0.001)$.

Table 5 below shows the result of the path coefficient analysis for the model. According to findings, knowledge transfer has a significant impact on innovative performance, knowledge transfer has a significant impact on employee creativity, automation has a significant impact on knowledge transfer, and knowledge worker has a significant impact on knowledge transfer. The study also found support for the mediating role of knowledge transfer between automation and innovative performance and the mediating role of knowledge transfer between automation and employee creativity. However, the study did not find support for the mediating role of knowledge transfer between knowledge workers and innovative performance and the mediating role of knowledge transfer between knowledge workers and creativity.

Table 5. Path Coefficient Analysis for Model.

\begin{tabular}{|c|c|c|c|c|c|}
\hline \multirow[b]{2}{*}{ Effect } & \multirow{2}{*}{$\begin{array}{l}\text { Original } \\
\text { Coefficient }\end{array}$} & \multicolumn{4}{|c|}{ Standard Bootstrap Results } \\
\hline & & $\begin{array}{l}\text { Standard } \\
\text { Error }\end{array}$ & $t$-Value & $\begin{array}{c}p \text {-Value } \\
\text { (2-Sided) }\end{array}$ & Outcome \\
\hline $\mathrm{KT} \rightarrow \mathrm{IP}$ & 0.703 & 0.042 & 16.776 & 0.000 & Supported \\
\hline $\mathrm{KT} \rightarrow \mathrm{EC}$ & 0.613 & 0.044 & 13.894 & 0.000 & Supported \\
\hline $\mathrm{AUT} \rightarrow \mathrm{KT}$ & 0.315 & 0.048 & 6.588 & 0.000 & Supported \\
\hline $\mathrm{KW} \rightarrow \mathrm{KT}$ & 0.405 & 0.057 & 7.093 & 0.001 & Supported \\
\hline $\mathrm{KW} \rightarrow \mathrm{KT} \rightarrow \mathrm{IP}$ & 0.0288 & 0.0494 & 0.0197 & 0.560 & Not-Supported \\
\hline $\mathrm{AUT} \rightarrow \mathrm{KT} \rightarrow \mathrm{IP}$ & 0.231 & 0.0332 & 0.261 & $<0.001$ & Supported \\
\hline $\mathrm{KW} \rightarrow \mathrm{KT} \rightarrow \mathrm{EC}$ & 0.0086 & 0.0148 & 0.0123 & 0.561 & Not-Supported \\
\hline $\mathrm{AUT} \rightarrow \mathrm{KT} \rightarrow \mathrm{EC}$ & 0.0693 & 0.0121 & 0.171 & $<0.001$ & Supported \\
\hline
\end{tabular}

Additionally, this study examines the mediating effect of knowledge transfer between knowledge workers and employee creativity, as well as between automation and employee creativity by looking at the average of variances extracted (ave) of: knowledge worker (kwave), knowledge transfer (ktave), employee creativity (ecave), automation (autave), and innovative performance (ipave). As shown in Table 6, the study's results indicate a partial mediating effect of knowledge transfer on knowledge workers and employee creativity $(p=0.561 ; p>0.05)$. Knowledge workers have a significant effect on employee creativity $(p=0.015 ; p<0.05)$ but an insignificant effect on knowledge transfer $(p=0.560 ; p>0.05)$. More so, the result indicates a full mediating effect of knowledge transfer between automation and employee creativity $(p=0.001 ; p<0.05)$. Automation has a significant effect on both knowledge transfer and employee creativity $(p=0.001 ; p<0.05)$.

Furthermore, this study examines the mediating effect of knowledge transfer between knowledge workers and innovative performance, as well as between automation and innovative performance. As shown in Table 7, the study's results indicate a partial mediating effect of knowledge transfer between knowledge workers and innovative performance $(p=0.560 ; p>0.05)$. Knowledge workers have a significant effect on innovative performance $(p=0.005 ; p<0.05)$ but an insignificant effect on knowledge transfer $(p=0.560 ; p>0.05)$. The result also indicates a full mediating effect of knowledge transfer between automation and innovative performance $(p=0.001 ; p<0.05)$. Automation has a significant effect on both knowledge transfer and innovative performance $(p=0.001 ; p<0.05)$. 
Table 6. Mediating Role between Automation, KW, and EC.

\begin{tabular}{|c|c|c|c|c|c|c|c|c|}
\hline \multirow[b]{2}{*}{ Type } & \multirow[b]{2}{*}{ Effect } & \multicolumn{7}{|c|}{$\begin{array}{c}\text { 95\% C.I. } \\
\text { (Confidence } \\
\text { Interval) (a) }\end{array}$} \\
\hline & & Estimate & $\begin{array}{l}\text { SE (Standard } \\
\text { Error) }\end{array}$ & Lower & Upper & B & $\mathbf{Z}$ & $p$ \\
\hline \multirow[t]{2}{*}{ Indirect } & kwave $\Rightarrow$ avekt $\Rightarrow$ ecave & 0.00862 & 0.0148 & -0.0204 & 0.0377 & 0.0129 & 0.582 & 0.561 \\
\hline & autave $\Rightarrow$ avekt $\Rightarrow$ ecave & 0.06928 & 0.0121 & 0.0456 & 0.0930 & 0.1710 & 5.727 & $<0.001$ \\
\hline \multirow[t]{3}{*}{ Component } & kwave $\Rightarrow$ avekt & 0.04048 & 0.0694 & -0.0956 & 0.1765 & 0.0308 & 0.583 & 0.560 \\
\hline & avekt $\Rightarrow$ ecave & 0.21305 & 0.0250 & 0.1641 & 0.2620 & 0.4197 & 8.538 & $<0.001$ \\
\hline & autave $\Rightarrow$ avekt & 0.32518 & 0.0421 & 0.2427 & 0.4077 & 0.4075 & 7.723 & $<0.001$ \\
\hline \multirow[t]{2}{*}{ Direct } & kwave $\Rightarrow$ ecave & 0.08136 & 0.0340 & 0.0148 & 0.1479 & 0.1218 & 2.396 & 0.017 \\
\hline & autave $\Rightarrow$ ecave & 0.01869 & 0.0221 & -0.0247 & 0.0621 & 0.0461 & 0.845 & 0.398 \\
\hline \multirow[t]{2}{*}{ Total } & kwave $\Rightarrow$ ecave & 0.08999 & 0.0371 & 0.0173 & 0.1627 & 0.1347 & 2.427 & 0.015 \\
\hline & autave $\Rightarrow$ ecave & 0.08797 & 0.0225 & 0.0439 & 0.1320 & 0.2172 & 3.912 & $<0.001$ \\
\hline
\end{tabular}

Table 7. Mediating Role between Automation, KW, and IP.

\begin{tabular}{ccccccccc}
\hline & & \multicolumn{5}{c}{ 95\% C.I. (a) } \\
\hline Type & Effect & Estimate & SE & Lower & Upper & $\boldsymbol{\beta}$ & $\mathbf{Z}$ & $\boldsymbol{p}$ \\
\hline \multirow{2}{*}{ Indirect } & kwave $\Rightarrow$ avekt $\Rightarrow$ ipave & 0.0288 & 0.0494 & -0.068 & 0.125 & 0.0197 & 0.583 & 0.560 \\
& autave $\Rightarrow$ avekt $\Rightarrow$ ipave & 0.2310 & 0.0332 & 0.1661 & 0.296 & 0.2613 & 6.968 & $<0.001$ \\
Component & kwave $\Rightarrow$ avekt & 0.0405 & 0.0694 & -0.0956 & 0.177 & 0.0308 & 0.583 & 0.560 \\
& avekt $\Rightarrow$ ipave & 0.7105 & 0.0440 & 0.6244 & 0.797 & 0.6414 & 16.161 & $<0.001$ \\
& autave $\Rightarrow$ avekt & 0.3252 & 0.0421 & 0.2427 & 0.408 & 0.4075 & 7.723 & $<0.001$ \\
Direct & kwave $\Rightarrow$ ipave & 0.1876 & 0.0598 & 0.0703 & 0.305 & 0.1287 & 3.135 & 0.002 \\
& autave $\Rightarrow$ ipave & 0.0469 & 0.0390 & -0.0296 & 0.123 & 0.0530 & 1.202 & 0.229 \\
Total & kwave $\Rightarrow$ ipave & 0.2163 & 0.0776 & 0.0642 & 0.368 & 0.1484 & 2.787 & 0.005 \\
& autave $\Rightarrow$ ipave & 0.2779 & 0.0471 & 0.1856 & 0.370 & 0.3144 & 5.903 & $<0.001$ \\
\hline
\end{tabular}

Figure 1 shows that the $\mathrm{R}^{2}$ for IP is 0.494 , the $\mathrm{R}^{2}$ of employee creativity (EC) is 0.376 , and knowledge transfer (KT) is 0.342 , and all are proven to be significant predictors. Thus, knowledge workers (KW) and automation (AUT) showed predictive power on knowledge transfer (KT) (34.2\%). Knowledge transfer (KT) showed predictive power over employee creativity (EC) $(37.6 \%)$, and knowledge transfer (KT) proved to be a strong predictor of innovative performance (IP) (49.4\%).

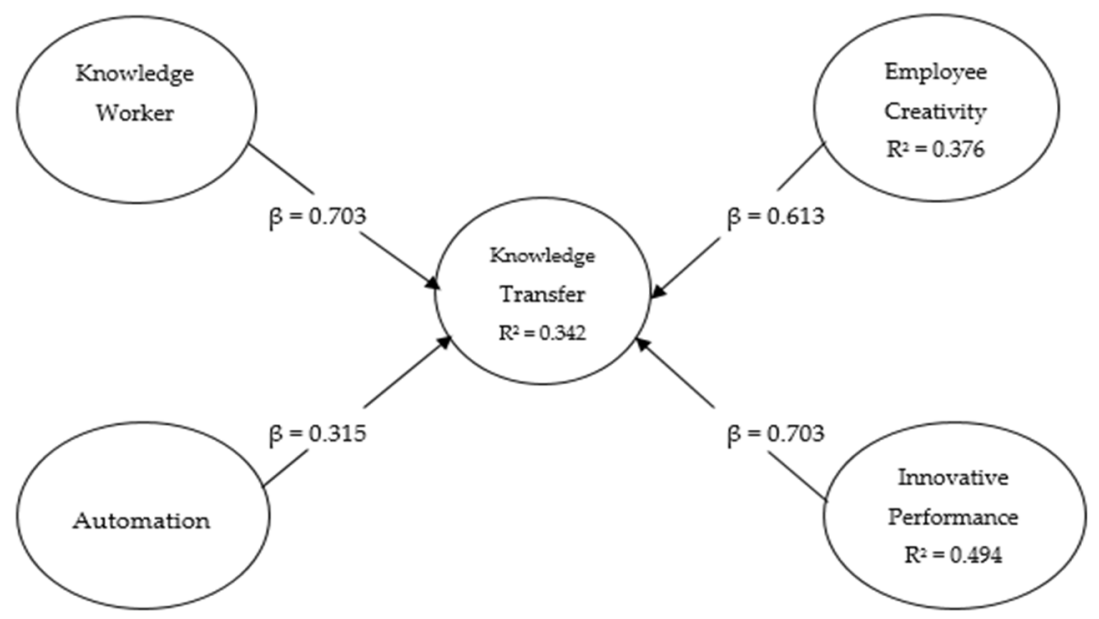

Figure 1. Tested Model of the Study. 


\section{Discussion and Theoretical Implication}

\subsection{Discussion}

This paper tested the mediating role of knowledge transfer between automation, knowledge worker, employee creativity, and innovative performance. The relationship between knowledge worker and knowledge transfer is developed in line with the principles of the knowledge worker productivity theory. Knowledge transfer as a mediating variable explains the relationship between knowledge workers, employee creativity, and innovative performance. Additionally, the relationship between automation and knowledge transfer was developed in line with the principles of technology acceptance model. Knowledge transfer as a mediating variable explains the relationship between automation, employee creativity, and innovative performance. At the same time, knowledge transfer enhances employee creativity and innovative performance. Looking at the relationship between the research's constructs, this paper provides partial empirical evidence using data of 384 employees at the firm.

The result found support for the mediating role of knowledge transfer between automation and employee creativity, and the mediating role of knowledge transfer between automation and innovative performance. However, the study found partial support for knowledge transfer mediating the relationship between knowledge worker and employee creativity, and knowledge transfer mediating the relationship between knowledge worker and innovative performance.

Knowledge transfer has a significant impact on employees' creativity and innovative performance $[17,64,104]$. Knowledge transfer significantly impacts innovative performance. Knowledge transfer reliability and accuracy significantly influence innovative performance [64]. Knowledge embedded in knowledge workers developed from research has a high degree to build innovativeness in other employees [105]. However, the degree to which knowledge transfer affects innovative performance sometimes fluctuates [105]. However, this study did not reveal a fluctuating impact of knowledge transfer on innovative performance.

There is no empirical support for the relationship between automation activities and knowledge transfer. To the best of our understanding, no paper has examined the impact of automation on knowledge transfer and the relationship between automation, employee creativity, and innovative performance. However, just like knowledge workers, automation serves as a reference for knowledge representation which allows for unambiguous knowledge transfer among any group of humans [106]. Automation is built with tacit knowledge and therefore complements human knowledge. Automation supports other workers by not just taking over complicated tasks which frees up time but it also provides an opportunity for employees to learn new skills [107].

\subsection{Theoretical Implications}

By finding a significant impact of the activities of knowledge workers on knowledge transfer, this study supports the theory of knowledge worker productivity, stating that organizational management has moved from a labor-intensive perspective to a mechanized system where knowledge workers play a vital role in the transfer of knowledge for an organization's optimization [19]. This study reveals that knowledge transfer partially mediates the relationship between knowledge workers and the creativity of other workers. Knowledge transfer also partially mediates the relationship between knowledge workers and innovative performance of other workers. In a constructivist sense, knowledge is a set of expressions and assumptions about reality that are strongly linked to individual objectives and their attainment [108]. In general, this implies that knowledge workers expertise is realistic if it is not (significantly) conflicting with past knowledge and has shown to be effective in attaining actual organizational goals. This form of knowledge is referred to as non-viable knowledge, and it is in some manner inconsistent with or detrimental to earlier knowledge concerning a specific aim that struggles to find the appropriate path 
under extremely complex and difficult settings. As a result, other workers may find it difficult to accept the changes championed by knowledge workers.

Therefore, the ability of knowledge to be transferred from knowledge workers largely depends on the resistance or acceptance from other employees. Employees at the industrial firm in Japan may have resistance to learning from knowledge workers. It can also happen that the employees at the firm are less motivated to engage in knowledge transfer activities. This can be a result of limited trust in the activities of knowledge workers to effectively transfer required knowledge to other employees, which affects the degree of the substance of knowledge transfer, especially knowledge transfers that are hard to codify [109]. This will necessitate a greater understanding and trust in the framework, its implication, and the transmissible characteristics of knowledge workers.

The significant impact of automation on knowledge transfer is in line with the TAM supporting that automation activities have been widely accepted within the organization. Additionally, this research supports that automation is widely accepted in organizations and serves as vital knowledge resource. Automation processes improve the flow of knowledge within the organization [110]. This study also reveals the full mediation of knowledge transfer between automation activities and employee creativity and between automation activities and innovative performance of other workers. These findings support the idea that organizations have started to manage knowledge through diverse bases, hence assimilating the practicality of a wide range of technologies such as automation [111]. Human capabilities and knowledge are often hidden in rules sets and certain skills that are frequently absent from cognizant appreciation. As a result, most of the tasks performed by humans rely on intuitive knowledge, which is sometimes difficult to automate and codify [112].

Employee creativity is more crucial these days since it may help organizations gain a competitive advantage and improve performance [33]. Employees can get new ideas and knowledge from a variety of sources, including training programs and seminars, as well as knowledge sources such as knowledge workers and automation [113]. Improved tacit knowledge leads to more efficient production processes, more self-awareness, and better creative process learning. As a result, more tacit knowledge within the organization produces positive outcomes and a high level of creativity and innovation [114]. On the other hand, knowledge gained from training practices can help to develop new learning abilities and, as a result, boost the creation of new ideas. Employees require technical abilities in order to produce new ideas and solutions in their areas of responsibility. The knowledge that is explicit is easily transferrable [114]. Tacit knowledge has dynamic features that are most likely to have a beneficial impact on performance [115]. Investing in employees' skills also improves the organization's capacity to develop, produce new and original ideas, and sustain a competitive advantage. This is easily achieved through the mechanism of knowledge transfer.

\subsection{Implications for Practice}

In the acknowledgement of the knowledge-based perspective, management has attempted to uncover some of the elements that influence knowledge transfer within the business. Managers value their organization's resources with deeply held knowledge, such as automation and knowledgeable employees, since these resources are capable of achieving complicated tasks successfully. Automation and knowledge workers provide the organization with new learning chances for other employees to develop their creativity and innovativeness. As a result, firms may have knowledge-intensive resources such as knowledge workers and automation, but unless the information is transmitted, it will have little or no impact on other employees' creativity and innovation.

There is an emergent acknowledgement that the success of organizations does not rely on organizational resources such as equipment, but rather on knowledge embedded resources such as skilled workers [5]. This research indicates that the conventional idea of elements of production has been revised to include land, human capital, other capitals such as automation, and entrepreneurs. Knowledge-intensive sectors may find it difficult 
to create value without the activities of knowledge workers due to their innovative and creative abilities which are critical in the creation and maintenance of value as well as their long-term impact in the organizations. As a result, management should prioritize retaining knowledge workers to ensure other employees within the organization increase creativity and innovation.

Moreover, increased mechanization within the organization is an indication that automation activities remain essential to the organization, notably with the depth of knowledge that propels the growth of tools such as big data [116]. Automation helps organizations manage knowledge and information via diverse means and, as well, applies different forms of technology to integrate knowledge. Consistency, transparency, and reliability are all advantages of automation. These elements aid in the dissemination of knowledge to the relevant user by sharing it with the proper departments within the organization. Automation implementation is increasingly seen as a requirement rather than a core competence. Organizational processes, systems, and programs that are fully automated assist in linking and aligning company goals with external and internal economic and commercial contexts [117]. Automation can be productive and effective with information and communication exchange. Automation of important operations by industry standards not only allows for decentralized functions and individual responsibilities, but also saves time, money, and resources. Organizations open to a "new" kind of knowledge from knowledge workers and automation will emerge as dominant in their niche.

\section{Conclusions}

The proposed literature review and theoretical framework are aimed at evaluating the mediating role of knowledge transfer on knowledge workers, automation, innovative performance, and employee creativity. This study found support for the mediating role of knowledge transfer between automation and employee creativity as well as between automation and innovative performance. On the contrary, the study found partial support for the mediating role of knowledge transfer between knowledge workers and employee creativity, as well as between knowledge workers and innovative performance. This study also highlighted the importance of automation and knowledge workers as knowledge bases within the organization. Employee creativity and innovative performance become easy in a work environment characterized by a high degree of knowledge transfer [118].

The acquisition and transmission of knowledge within the organization are one of the duties of knowledge workers [6]. Automation creates tacit knowledge, which employees can acquire through learning $[119,120]$. However, few studies have assessed the impact of automation on knowledge transfer. This study adopts the theories of knowledge worker productivity and TAM to demonstrate the mediating mechanism between automation, knowledge workers, and employee outcomes.

This study has a couple of limitations. To begin with, it could be beneficial for supervisors to provide information regarding employees' creativity and innovative performance. It was, however, challenging to get data from the firm through the time-lapse technique during the period of the COVID-19 pandemic, which would have fit the ultimate goal of data collection. Secondly, this study had to adopt the judgmental sampling non-probability sampling technique [85]. Employees familiar with automation and knowledge worker activities were targeted. Therefore, future research could adopt the time-lag technique where the activities of automation and knowledge workers could be measured at two different points in time, while supervisors could provide feedback on the innovative performance and creativity of other workers.

Most studies on knowledge transfer have focused on tacit knowledge [119,121]. Other studies have examined the impact of explicit knowledge on innovative performance [64,122]. The breakdown of knowledge into tacit and explicit knowledge is due to the fact that the transfer of explicit knowledge can be facilitated with improved technology such as automation [123]. Therefore, this study recommends further studies to be carried on the impact of 
automation on tacit knowledge transfer. Additionally, future studies can examine the role of tacit and explicit knowledge in employees' creativity and innovative performance.

Author Contributions: Conceptualization, methodology, analysis, writing-original draft preparation, writing - review and editing, N.J.I.M.; conceptualization and supervision, G.K. All authors have read and agreed to the published version of the manuscript.

Funding: This research received no external funding.

Institutional Review Board Statement: Ethical review and approval were waived for this study due to the fact that our university is responsible for giving approval only for those fields of health research that are directly related to patients. The Institutional Review Board Statement, which is in Turkish (the national language of Northern Cyprus), is as follows: “Üniversitemiz İktisadi ve İdari Bilimler Fakültesi öğretim üyesi Yar. Doç. Dr. Georgiana Karadas danışmanlığında Nding Junior Itoe Mote tarafından hazırlanmış olan "The knowledge worker and machine: The new value to the organization" adlı çalışmanın Etik Kurulumuz başkanlı̆̆ınca Etik Kurulda görüşülmesine gerek olmadığına ve mua yet talebinin uygun olduğuna karar verilmiştir.Gereğini saygılarımla arz ederim." states that our exemption request for data for our research has been approved by the Ethics Committee Board at our university, Cyprus International University. TBF.00.0-020-11137 is the number of the Institutional Review Board's approval.

Informed Consent Statement: Participant consent was waived due to the fact that the research does not fall under the field of health and therefore does not directly relate to patients. Additionally, the employees at the industrial firm in Japan were not compelled to provide data for the study; rather, they volunteered. As a result, our university, Cyprus International University, waived the Informed Consent.

Data Availability Statement: The corresponding author can provide the data used in this study upon request.

Acknowledgments: We want to give thanks to the management of the industrial firm in Japan for accepting our request to provide data during the lockdown season caused by COVID-19. We also want to especially thank the human resource manager for following up with the team for adequate and prompt feedback.

Conflicts of Interest: The authors declare no conflict of interest.

\section{References}

1. Wang, F.; Zhang, M.; Das, A.K.; Weng, H.; Yang, P. Aiming at the organizational sustainable development: Employees' pro-social rule breaking as response to high performance expectations. Sustainability 2021, 13, 267. [CrossRef]

2. Figurska, I.; Sokol, A. Potential of Creative Knowledge of Workers and their Development in a Sustainable Organisation. Eur. Res. Stud. J. 2020, 23, 628-650. [CrossRef]

3. Issahaka, A.W.; Lines, R. Research literature on leadership of knowledge workers: Where are we, and where should we be heading? J. Intellect. Cap. 2021, 22, 122-148. [CrossRef]

4. Sukaatmadja, I.P.G.; Yasa, N.N.K.; Rahyuda, H.; Setini, M.; Dharmanegara, I.B.A. Competitive advantage to enhance internationalization and marketing performance woodcraft industry: A perspective of resource-based view theory. J. Proj. Manag. 2021, 6, 45-56. [CrossRef]

5. Celestine, N.A.; Perryer, C. The Determinants of Interorganizational Knowledge Coaching Success: Looking Ahead to the Future of Knowledge Transfer. In Effective Knowledge Management Systems in Modern Society; IGI Global: Hershey, PA, USA, 2019.

6. Manyika, J.; Chui, M.; Bughin, J.; Dobbs, R.; Bisson, P.; Marrs, A. Disruptive Technologies: Advances that Will Transform Life, Business, and the Global Economy; McKinsey Global Institute: New York, NY, USA, 2013; Volume 180, pp. 17-21.

7. Hamel, G. What Matters Now. Strateg. Dir. 2012, 28, 5. [CrossRef]

8. Huang, X.; Yun, S.; Zhu, J.; Du, T.; Zhang, C.; Li, X. Mesophilic anaerobic co-digestion of aloe peel waste with dairy manure in the batch digester: Focusing on mixing ratios and digestate stability. Bioresour. Technol. 2016, 218, 62-68. [CrossRef]

9. Kerja, E.P.T. Available online: https://scholar.google.com.hk/scholar?hl=en\&as_sdt=0\%2C5\&q=Kerja\%2C+E.+P.+T.+\%281967 $\% 29 .+\%$ E6 $\%$ B8 $\% 88 \%$ E7\%84\%A1No+Title+No+Title+No+Title.+Angewandte+Chemie+International\&btnG= (accessed on 17 December 2021).

10. Tafazzoli, M. Construction Automation and Sustainable Development. In Automation and Robotics in the Architecture, Engineering, and Construction Industry; Springer: Cham, Switzerland, 2022; pp. 73-95.

11. Yang, J. Individual attitudes and organisational knowledge sharing. Tour. Manag. 2008, 29, 345-353. [CrossRef] 
12. Bratianu, C.; Prelipcean, G.; Bejinaru, R. Exploring the latent variables which support SMEs to become learning organizations. Manag. Mark. 2020, 15, 154-171. [CrossRef]

13. Barão, A.; de Vasconcelos, J.B.; Rocha, Á.; Pereira, R. A knowledge management approach to capture organizational learning networks. Int. J. Inf. Manag. 2017, 37, 735-740. [CrossRef]

14. Maravilhas, S.; Martins, J. Strategic knowledge management a digital environment: Tacit and explicit knowledge in Fab Labs. J. Bus. Res. 2019, 94, 353-359. [CrossRef]

15. Abbas, J.; Kumari, K. Examining the relationship between total quality management and knowledge management and their impact on organizational performance: A dimensional analysis. J. Econ. Adm. Sci. 2021, ahead-of-print.

16. Arranz, N.; Arroyabe, M.F.; Molina-García, A.; Fernandez de Arroyabe, J.C. Incentives and inhibiting factors of eco-innovation in the Spanish firms. J. Clean. Prod. 2019, 220, 167-176. [CrossRef]

17. Li, R.; Du, Y.F.; Tang, H.J.; Boadu, F.; Xue, M. MNEs' subsidiary HRM practices and firm innovative performance: A tacit knowledge approach. Sustainbility 2019, 11, 1388. [CrossRef]

18. Krylova, K.O.; Vera, D.; Crossan, M. Knowledge transfer in knowledge-intensive organizations: The crucial role of improvisation in transferring and protecting knowledge. J. Knowl. Manag. 2016, 20, 1045-1064. [CrossRef]

19. Shujahat, M.; Sousa, M.J.; Hussain, S.; Nawaz, F.; Wang, M.; Umer, M. Translating the impact of knowledge management processes into knowledge-based innovation: The neglected and mediating role of knowledge-worker productivity. J. Bus. Res. 2019, 94, 442-450. [CrossRef]

20. Rodriguez, I.; Nottensteiner, K.; Leidner, D.; Durner, M.; Stulp, F.; Albu-Schaffer, A. Pattern Recognition for Knowledge Transfer in Robotic Assembly Sequence Planning. IEEE Robot. Autom. Lett. 2020, 5, 3666-3673. [CrossRef]

21. Maschler, B.; Weyrich, M. Deep Transfer Learning for Industrial Automation: A Review and Discussion of New Techniques for Data-Driven Machine Learning. IEEE Ind. Electron. Mag. 2021, 15, 65-75. [CrossRef]

22. Strathmore, S.U.; Ghaghda, J. Assessment of Determinants of Enterprise Resource Planning Implementation by Small and Medium Enterprises in Kenya: A Case of Nairobi County. Ph.D. Thesis, Strathmore University, Nairobi, Kenya, 2018.

23. Rizky, C.A. The struggle of African Americans against racial discrimination in Angie Thomas' The Hate U Give. Bachelor's Thesis, Sanata Dharma University, Yogyakarta, Indonesia, 2020.

24. Bettoni, A.; Montini, E.; Righi, M.; Villani, V.; Tsvetanov, R.; Borgia, S.; Secchi, C.; Carpanzano, E. Mutualistic and adaptive human-machine collaboration based on machine learning in an injection moulding manufacturing line. Procedia CIRP 2020, 93, 395-400. [CrossRef]

25. Ali, A.A.; Paris, L.; Gunasekaran, A. Key factors influencing knowledge sharing practices and its relationship with organizational performance within the oil and gas industry. J. Knowl. Manag. 2019, 23, 1806-1837.

26. Steen, T.; Schott, C. Public sector employees in a challenging work environment. Public Adm. 2019, 97, 3-10. [CrossRef]

27. Zou, W.; Lo, D.; Chen, Z.; Xia, X.; Feng, Y.; Xu, B. How Practitioners Perceive Automated Bug Report Management Techniques. IEEE Trans. Softw. Eng. 2020, 46, 836-862. [CrossRef]

28. Anzola-Román, P.; Bayona-Sáez, C.; García-Marco, T. Organizational innovation, internal R\&D and externally sourced innovation practices: Effects on technological innovation outcomes. J. Bus. Res. 2018, 91, 233-247.

29. Drucker, P.F. Knowledge-worker productivity: The biggest challenge. IEEE Eng. Manag. Rev. 1999, 27, 41-50. [CrossRef]

30. Santoro, G.; Vrontis, D.; Thrassou, A.; Dezi, L. The Internet of Things: Building a knowledge management system for open innovation and knowledge management capacity. Technol. Forecast. Soc. Chang. 2018, 136, 347-354. [CrossRef]

31. Ya Lvovich, I.; Lvovich, Y.E.; Preobrazhenskiy, A.P.; Preobrazhenskiy, Y.P.; Choporov, O.N. Modeling of information processing in the Internet of Things at agricultural enterprises. In IOP Conference Series: Earth and Environmental Science; IOP Publishing: Bristol, UK, 2019; Volume 315.

32. Beheshti, A.; Schiliro, F.; Ghodratnama, S.; Amouzgar, F.; Benatallah, B.; Yang, J.; Motahari-Nezhad, H.R. iprocess: Enabling iot platforms in data-driven knowledge-intensive processes. In Business Process Management Forum; Springer: Cham, Switzerland, 2018; pp. 108-126.

33. Argote, L.; Ingram, P. Knowledge transfer: A basis for competitive advantage in firms. Organ. Behav. Hum. Decis. Process. 2000, 82, 150-169. [CrossRef]

34. Nonaka, I.; Takeuchi, H. The Knowledge-Creating Company: How Japanese Companies Create the Dynamics of Innovation (Volume 105); Oxford University Press: Oxford, NY, USA, 1995.

35. Razzaq, S.; Shujahat, M.; Hussain, S.; Nawaz, F.; Wang, M.; Ali, M.; Tehseen, S. Knowledge management, organizational commitment and knowledge-worker performance: The neglected role of knowledge management in the public sector. Bus. Process Manag. J. 2019, 25, 923-947. [CrossRef]

36. Zaim, H.; Keceli, Y.; Jaradat, A.; Kastrati, S. The effects of knowledge management processes on human resource management: Mediating role of knowledge utilization. J. Sci. Technol. Policy Manag. 2018, 9, 310-328. [CrossRef]

37. Senge, P.M. The Art and Practice of the learning Organization; Currency Doubleday: New York, NY, USA, 1990.

38. Udriyah; Tham, J.; Ferdous Azam, S.M. The effects of market orientation and innovation on competitive advantage and business performance of textile smes. Manag. Sci. Lett. 2019, 9, 1419-1428.

39. Butt, M.A.; Nawaz, F.; Hussain, S.; Sousa, M.J.; Wang, M.; Sumbal, M.S.; Shujahat, M. Individual knowledge management engagement, knowledge-worker productivity, and innovation performance in knowledge-based organizations: The implications for knowledge processes and knowledge-based systems. Comput. Math. Organ. Theory 2019, 25, 336-356. [CrossRef] 
40. Pasher, E.; Ronen, T. The Complete Guide to Knowledge Management: A Strategic Plan to Leverage Your Company's Intellectual Capital; John Wiley \& Sons: Hoboken, NJ, USA, 2011; Volume 65, ISBN 9780470881293.

41. Bosch-Sijtsema, P.M.; Ruohomäki, V.; Vartiainen, M. Knowledge work productivity in distributed teams. J. Knowl. Manag. 2009, 13, 533-546. [CrossRef]

42. Davis, F.D. IT usefulness and ease of use. MIS Q. 1989, 13, 319-340. [CrossRef]

43. Jennings, D.F.; Seaman, S.L. Aggressiveness of response to new business opportunities following deregulation: An empirical study of established financial firms. J. Bus. Ventur. 1990, 5, 177-189. [CrossRef]

44. Hamid, A.; Sarmad, A. Multi-dimensional criteria for the evaluation of e-health services. Int. J. Healthc. Deliv. Reform Initiat. 2009, 1, 1-18. [CrossRef]

45. Ra, S.; Shrestha, U.; Khatiwada, S.; Yoon, S.W.; Kwon, K. The rise of technology and impact on skills. Int. J. Train. Res. 2019, 17, 26-40. [CrossRef]

46. Aly, H. Digital transformation, development and productivity in developing countries: Is artificial intelligence a curse or a blessing? Rev. Econ. Polit. Sci. 2020, ahead-of-print. [CrossRef]

47. Shimmura, T.; Ichikari, R.; Okuma, T. Human-Robot Hybrid Service System Introduction for Enhancing Labor and Robot Productivity. In Advances in Production Management Systems. Towards Smart and Digital Manufacturing; Springer: Cham, Switzerland, 2020; pp. 661-669.

48. Luo, X.; Tong, S.; Fang, Z.; Qu, Z. Frontiers: Machines vs. humans: The impact of artificial intelligence chatbot disclosure on customer purchases. Mark. Sci. 2019, 38, 937-947. [CrossRef]

49. Cowgill, B. Bias and Productivity in Humans and Machines. In Upjohn Institute Working Paper 19-309; W.E. Upjohn Institute for Employment Research: Kalamazoo, MI, USA, 2019.

50. Richter, N.; Jackson, P.; Schildhauer, T. Outsourcing creativity: An abductive study of open innovation using corporate accelerators. Creat. Innov. Manag. 2018, 27,69-78. [CrossRef]

51. Ahmed Elsayed, W.; Mustafa Abdel-ghani, A. Learning Organization and Its Influence on Organization' Resilience and Creativity in Mansoura Oncology Center. Egypt. J. Heal. Care 2020, 11, 485-499. [CrossRef]

52. Yildiz, B.; Uzun, S.; Coşkun, S.S. Drivers of innovative behaviors: The moderator roles of perceived organizational support and psychological empowerment. Int. J. Organ. Leadersh. 2017, 6, 341-360. [CrossRef]

53. Zhang, X. Linking empowering leadership and employee creativity: The influence of psychological empowerment, intrinsic motivation, and creative process engagement. Dev. Learn. Organ. Int. J. 2010, 24, 4-9.

54. Escribá-Carda, N.; Balbastre-Benavent, F.; Teresa Canet-Giner, M. Employees' perceptions of high-performance work systems and innovative behaviour: The role of exploratory learning. Eur. Manag. J. 2017, 35, 273-281. [CrossRef]

55. Jeong, I.; Shin, S.J. High-Performance Work Practices and Organizational Creativity During Organizational Change: A Collective Learning Perspective. J. Manag. 2019, 45, 909-925. [CrossRef]

56. Chang, L.L.; Backman, K.F.; Huang, Y.C. Creative tourism: A preliminary examination of creative tourists' motivation, experience, perceived value and revisit intention. Int. J. Cult. Tour. Hosp. Res. 2014, 8, 401-419. [CrossRef]

57. Al-Husseini, S.; El Beltagi, I.; Moizer, J. Transformational leadership and innovation: The mediating role of knowledge sharing amongst higher education faculty. Int. J. Leadersh. Educ. 2021, 24, 670-693. [CrossRef]

58. Baldwin, M. Social Work, Critical Reflection and the Learning Organization; Routledge: Oxford, UK, 2016.

59. Ghaffari, S.; Burgoyne, J.; Shah, I.; Nazri, M. Perceptions of Learning Organization Dimensions among Non-academic Employees of Top Public Universities in Malaysia. Aust. J. Basic Appl. Sci. 2017, 11, 107-116.

60. Hourani, N. The Role of Learning Organization Dimensions on Enhancing Knowledge Creation: The Case of Commercial Banks Working in Jordan. Int. J. Bus. Manag. 2019, 14, 153. [CrossRef]

61. Nazari, K.; Pihie, Z. Assessing learning organization dimensions and demographic factors in technical and vocational colleges in Iran. Int. J. Bus. Soc. 2012, 3, 210-219.

62. Alzghoul, A.; Elrehail, H.; Emeagwali, O.L.; AlShboul, M.K. Knowledge management, workplace climate, creativity and performance: The role of authentic leadership. J. Work. Learn. 2018, 30, 592-612. [CrossRef]

63. Muñoz-Pascual, L.; Galende, J. The impact of knowledge and motivation management on creativity: Employees of innovative Spanish companies. Empl. Relations 2017, 39, 732-752. [CrossRef]

64. Abu Hasan, N.; Omar, N.A.; Zainuddin, M.N.; Mukhtar, D. The interaction effects of knowledge transfer on knowledge assets and innovative performance relationship. Malays. J. Soc. Sp. 2020, 16, 69-83. [CrossRef]

65. Hurmelinna-Laukkanen, P.; Olander, H. Coping with rivals' absorptive capacity in innovation activities. Technovation 2014, 34, 3-11. [CrossRef]

66. Hee, O.C.; Hui, O.K.; Rizal, A.M.; Kowang, T.O.; Fei, G.C. Determinants of Innovative Performance in the Service Industry: A Review. Int. J. Acad. Res. Bus. Soc. Sci. 2018, 8, 379-388. [CrossRef]

67. Yu, M.C.; Mai, Q.; Tsai, S.B.; Dai, Y. An empirical study on the organizational trust, employee-organization relationship and innovative behavior from the integrated perspective of social exchange and organizational sustainability. Sustainbility 2018, 10, 864. [CrossRef]

68. Tian, M.; Deng, P.; Zhang, Y.; Salmador, M.P. How does culture influence innovation? A systematic literature review. Manag. Decis. 2018, 56, 1088-1107. [CrossRef] 
69. Baradarani, S.; Kilic, H. Service innovation in the hotel industry: Culture, behavior, performance. Serv. Ind. J. 2018, 38, 897-924. [CrossRef]

70. Abdi, K.; Mardani, A.; Senin, A.A.; Tupenaite, L.; Naimaviciene, J.; Kanapeckiene, L.; Kutut, V. The effect of knowledge management, organizational culture and organizational learning on innovation in automotive industry. J. Bus. Econ. Manag. 2018, 19, 1-19. [CrossRef]

71. Çömlek, O.; Kitapçı, H.; Çelik, V.; Özşahin, M. The effects of organizational learning capacity on firm innovative performance. Procedia-Soc. Behav. Sci. 2012, 41, 367-374. [CrossRef]

72. Örtenblad, A. What does "learning organization" mean? Learn. Organ. 2018, 25, 150-158. [CrossRef]

73. Garvin, D.A.; Edmondson, A.C.; Gino, F. Is yours a learning organization? Harv. Bus. Rev. 2008, 86, 109.

74. DeLone, W.H.; McLean, E.R. The DeLone and McLean model of information systems success: A ten-year update. J. Manag. Inf. Syst. 2003, 19, 9-30.

75. Acosta-Prado, J.C.; López-Montoya, O.H.; Sanchís-Pedregosa, C.; Vázquez-Martínez, U.J. Sustainable Orientation of Management Capability and Innovative Performance: The Mediating Effect of Knowledge Management. Sustainability 2020, 12, 1366. [CrossRef]

76. Zeng, P.; Sheng, C.; Jin, M. A learning framework based on weighted knowledge transfer for holiday load forecasting. J. Mod. Power Syst. Clean Energy 2019, 7, 329-339. [CrossRef]

77. Li, J.; Monroe, W.; Ritter, A.; Galley, M.; Gao, J.; Jurafsky, D. Deep reinforcement learning for dialogue generation. In Proceedings of the 2016 Conference on Empirical Methods in Natural Language Processing, Austin, TX, USA, 1-5 November 2016; pp. $1192-1202$.

78. Martinkenaite, I. Antecedents of knowledge transfer in acquisitions. Balt. J. Manag. 2012, 7, 167-184. [CrossRef]

79. Yang, Q.; Mudambi, R.; Meyer, K.E. Conventional and reverse knowledge flows in multinational corporations. J. Manag. 2008, 34, 882-902.

80. Liu, M.L.; Lin, C.P.; Joe, S.W.; Chen, K.J. Modeling knowledge sharing and team performance: The interactions of ethical leadership and ambidexterity with politics and job complexity. Manag. Decis. 2019, 57, 1472-1495. [CrossRef]

81. Carreira, S.; Amado, N.; Jacinto, H. Venues for analytical reasoning problems: How children produce deductive reasoning. Educ. Sci. 2020, 10, 169. [CrossRef]

82. Zalaghi, H.; Khazaei, M. The Role of Deductive and Inductive Reasoning in Accounting Research and Standard Setting. Asian J. Financ. Account. 2016, 8, 23. [CrossRef]

83. Hyde, K.F. Recognising deductive processes in qualitative research. Qual. Mark. Res. Int. J. 2000, 3, 82-90. [CrossRef]

84. Ciesielska, M.; Jemielniak, D. Qualitative methodologies in organization studies. Qual. Methodol. Organ. Stud. 2017, 2, 1-264.

85. Karatepe, O.M.; Karadas, G. Service employees' fit, work-family conflict, and work engagement. J. Serv. Mark. 2016, 30, 554-566. [CrossRef]

86. Karatepe, O.M. High-performance work practices and hotel employee performance: The mediation of work engagement. Int. J. Hosp. Manag. 2013, 32, 132-140. [CrossRef]

87. Shmueli, G.; Sarstedt, M.; Hair, J.F.; Cheah, J.H.; Ting, H.; Vaithilingam, S.; Ringle, C.M. Predictive model assessment in PLS-SEM: Guidelines for using PLSpredict. Eur. J. Mark. 2019, 53, 2322-2347. [CrossRef]

88. Körber, M. Theoretical considerations and development of a questionnaire to measure trust in automation. Adv. Intell. Syst. Comput. 2019, 823, 13-30.

89. Schwartz, D.G. Integrating knowledge transfer and computer-mediated communication: Categorizing barriers and possible responses. Knowl. Manag. Res. Pract. 2007, 5, 249-259. [CrossRef]

90. Zahra, S.A.; Bogner, W.C. Technology strategy and software new ventures' performance: Exploring the moderating effect of the competitive environment. J. Bus. Ventur. 2000, 15, 135-173. [CrossRef]

91. Zhou, J.; George, J.M. When Job Dissatisfaction Leads to Creativity: Encouraging the Expression of Voice. Acad. Manag. J. 2001, 44, 682-696.

92. Matear, S.; Gra, B.J.; Garrett, T. Market orientation, brand investment, new service development, market position and performance for service organisations. Int. J. Serv. Ind. Manag. 2004, 15, 284-301. [CrossRef]

93. Henseler, J. Bridging Design and Behavioral Research With Variance-Based Structural Equation Modeling. J. Advert. 2017, 46, 178-192. [CrossRef]

94. Amegbe, H.; Hanu, C.; Mensah, F. Achieving service quality and students loyalty through intimacy and trust of employees of universities: A test case of Kenyan universities. Int. J. Educ. Manag. 2019, 33, 359-373. [CrossRef]

95. Mandal, S. Exploring the significance of big data infrastructure in dynamic capability development: A supply chain resilience perspective. Int. J. Work Organ. Emot. 2020, 11, 247-264. [CrossRef]

96. Kautish, P.; Sharma, R.; Khare, A. Multi-Item Scale Development for Online Consumption Emotion Construct And Psychometric Evaluation for Relationship Marketing. J. Relatsh. Mark. 2020, 20, 91-134. [CrossRef]

97. Pavlov, G.; Maydeu-Olivares, A.; Shi, D. Using the Standardized Root Mean Squared Residual (SRMR) to Assess Exact Fit in Structural Equation Models. Educ. Psychol. Meas. 2021, 81, 110-130. [CrossRef] [PubMed]

98. Hair, J.F.; Sarstedt, M.; Hopkins, L.; Kuppelwieser, V.G. Partial least squares structural equation modeling (PLS-SEM): An emerging tool in business research. Eur. Bus. Rev. 2014, 26, 106-121. [CrossRef]

99. Onainor, E.R. Language as a Mirror of Culture. J. Tarbiyah 2019, 1, 105-112. 
100. Gefen, D. Reflections on the dimensions of trust and trustworthiness among online consumers. ACM SIGMIS Database DATABASE Adv. Inf. Syst. 2002, 33, 38-53. [CrossRef]

101. Salmerón-Gómez, R.; García-García, C.; García-Pérez, J. A Guide to Using the R Package "multiColl” for Detecting Multicollinearity. Comput. Econ. 2021, 57, 529-536. [CrossRef]

102. Fornell, C.; Larcker, D.F. Evaluating Structural Equation Models with Unobservable Variables and Measurement Error. J. Mark. Res. 1981, 18, 39-51. [CrossRef]

103. Lütjens, B.; Everett, M.; How, J.P. Safe reinforcement learning with model uncertainty estimates. In Proceedings of the 2019 International Conference on Robotics and Automation (ICRA), Montreal, QC, Canada, 20-24 May 2019; pp. 8662-8668.

104. Thuan, L.C. Motivating follower creativity by offering intellectual stimulation. Int. J. Organ. Anal. 2020, 28, 817-829. [CrossRef]

105. Ibidunni, A.S.; Kolawole, A.I.; Olokundun, M.A.; Ogbari, M.E. Knowledge transfer and innovation performance of small and medium enterprises (SMEs): An informal economy analysis. Heliyon 2020, 6, e04740. [CrossRef]

106. Fiorini, S.R.; Bermejo-Alonso, J.; Goncalves, P.; Pignaton De Freitas, E.; Olivares Alarcos, A.; Olszewska, J.I.; Prestes, E.; Schlenoff, C.; Ragavan, S.V.; Redfield, S.; et al. A Suite of Ontologies for Robotics and Automation [Industrial Activities]. IEEE Robot. Autom. Mag. 2017, 24, 8-11. [CrossRef]

107. Sanzogni, L.; Guzman, G.; Busch, P. Artificial intelligence and knowledge management: Questioning the tacit dimension. Prometheus 2017, 35, 37-56. [CrossRef]

108. Gartmeier, M.; Bauer, J.; Gruber, H.; Heid, H. Negative Knowledge: Understanding Professional Learning and Expertise. Vocat. Learn. 2008, 1, 87-103. [CrossRef]

109. Butt, A.S.; Shah, S.H.H.; Noor, S.; Ali, M. Knowledge hiding in a buyer-supplier relationship: Present and future scope. Int. J. Knowl. Manag. 2020, 16, 18-29. [CrossRef]

110. Masui, L.S.; Arasa, R.; Mkamwa, T. Predicting Academic Staffs' Behavioural Intention to Create Knowledge by Using Policies In Private Universities of Tanzania. Int. J. Innov. Financ. Econ. Res. 2019, 7, 118-130.

111. Salimi, M.; Pourdarbani, R.; Nouri, B.A. Factors Affecting the Adoption of Agricultural Automation Using Davis's Acceptance Model (Case Study: Ardabil). Acta Technol. Agric. 2020, 23, 30-39. [CrossRef]

112. Kuada, J. Learning, Innovation and Entrepreneurship. In Private Enterprise-Led Economic Development in Sub-Saharan Africa; Palgrave Macmillan: London, UK, 2015; pp. 164-173. [CrossRef]

113. Zaitouni, M.; Ouakouak, M.L. Key predictors of individual creativity in a Middle Eastern culture: The case of service organizations. Int. J. Organ. Anal. 2018, 26, 19-42. [CrossRef]

114. Onputtha, S. The Role of Knowledge Transfer among Creative Behavior, Green Service Behavior and Environmental Performance In Logistics Service Industry. J. Manag. Inf. Decis. Sci. 2021, 24, 1-12.

115. Teece, D.J. Strategies for Managing Knowledge Assets: The Role of Firm Structure and Industrial Context. Long Range Plann. 2000, 33, 35-54. [CrossRef]

116. Kostrzewski, M.; Kosacka-Olejnik, M.; Werner-Lewandowska, K. Assessment of innovativeness level for chosen solutions related to Logistics 4.0. Procedia Manuf. 2019, 38, 621-628. [CrossRef]

117. Vishnoi, S.K.; Tripathi, A.; Bagga, T. Intelligent automation, planning \& implementation: A review of constraints. Int. J. Emerg. Technol. 2019, 10, 174-178.

118. Khan, S.; Mohiya, M. Determinants of SMEs employees' creativity and their impact on innovation at workplace. Manag. Sci. Lett. 2020, 10, 3865-3872. [CrossRef]

119. Seidler-de Alwis, R.; Hartmann, E. The use of tacit knowledge within innovative companies: Knowledge management in innovative enterprises. J. Knowl. Manag. 2008, 12, 133-147. [CrossRef]

120. Hamel, G. What Matters Now: How to in a World of Relentless Change, Ferocious Competition, and Unstoppable Innovation; Josey-Bass: San Francisco, CA, USA, 2012.

121. Pérez-Luño, A.; Alegre, J.; Valle-Cabrera, R. The role of tacit knowledge in connecting knowledge exchange and combination with innovation. Technol. Anal. Strateg. Manag. 2019, 31, 186-198. [CrossRef]

122. Asbari, M.; Wijayanti, L.M.; Hyun, C.C.; Purwanto, A.; Santoso, P.B. Effect of Tacit and Explicit Knowledge Sharing on Teacher Innovation Capability. Din. Pendidik. 2019, 14, 227-243. [CrossRef]

123. Koenig, R.; Bielik, M.; Dennemark, M.; Fink, T.; Schneider, S.; Siegmund, N. Levels of Automation in Urban Design Through Artificial Intelligence: A Framework to Characterize Automation Approaches. Built Environ. 2020, 46, 599-619. [CrossRef] 